\title{
Editors' Forum
}

\section{Maura Brighenti, Lucía Cavallero, Niccolò Cuppini and Alejo Stark Introduction: The Global Riot}

https://doi.org/10.1515/ngs-2020-0019

\begin{abstract}
The past few years have seen a number of "riots" - in Mexico City, Hong Kong, Chile, Ecuador, the United States, Argentina, France, the United Kingdom, and elsewhere. What do they have in common with one another and with other popular upheavals in history? How do they differ? What do they represent as sites of protest, resistance and rebellion? This forum explores the meaning of such riots through the meaning of the term itself, focusing mainly but not exclusively on the Global South, in theory and in the words and actions of rioters and the authorities who act to suppress them. If it is true the world has entered a "new age of riots," citizens and scholars must begin to reach some conceptual clarity of what a global riot is, and seeks to become.
\end{abstract}

Keywords: globalization, oppression, resistance, riots, strikes

The present issue is the result of a collective process of study and confrontation between researchers from different continents which converged at the international workshop we organized, "Riot as a Global Political Concept," which took place in Buenos Aires from 25-26 October 2018 with the support of the Academy of Global Humanities and Critical Theory.

Our concern in grappling with riots has to do with their proliferation throughout the planet and their relative elusiveness. If we think of the recent feminist riot in Mexico City or the riots in Hong Kong, Chile and Ecuador, if we consider the riots of Black Lives Matter in the United States or the riots of the banlieue in France (2005) and in the UK (2011), if we go back to the Los Angeles riot (1992) or in Argentina (2001), we face the multiple instances of "riots" that have transpired in the last few years and that were seen around the world. On the one

*Corresponding author: Niccolò Cuppini, University of Applied Sciences and Arts of Southern Switzerland, Manno, 6928, Switzerland, E-mail: Niccolo.Cuppini@supsi.ch

Maura Brighenti: Instituto de Altos Estudios Sociales, Universidad Nacional de San Martín, Buenos Aires, Argentina

Lucía Cavallero: University of Buenos Aires, Buenos Aires, Argentina

Alejo Stark: University of Michigan, Ann Arbor, MI, USA 
hand, we could point to the riot as a crucial form of contemporary mobilization, politics and social conflict - something that has been labeled "Le temps des émeutes" by authors like Alain Bertho. But, on the other hand, we are confronted with the deep heterogeneity of this phenomenon which makes the reduction of all of these instances to the same matrix quite questionable and problematic. In other words, it is often said that we live in a "new age of riots." However, despite the pervasive use of "riot" as a way to name these heterogeneous events, we sense a certain lack of conceptual clarity around what precisely "riot" implies. A theoretical and conceptual deficiency first of all, which seems mimetic to the riots as something with neither roots nor explanations, neither past nor future, something constitutively "spontaneous" and thereby immune to certain kinds of political organization. In short, theorists of the riot need to show that these unbridled "spontaneous" expressions of "force" have emerged as a form through which emancipatory demands are made and as part of a broader "repertoire" of class struggle.

Against this background, we have developed a genealogical approach that shows the multiple emergences and historical paths of the riot, thereby grappling with its continuities without constructing an all-encompassing sociological model. Secondly, we analyzed the riot beyond its conceptual "isolation.” The riot should be inscribed along a conceptual constellation that includes, though not exclusively, "revolution," "strike," "rebellion," "revolt," and "commune" with the aim of illuminating the riot both as a concept and as a performance. Thirdly, we grappled with the problem related to the processes of subjectification in relation to this constellation. In that sense, we considered how, in the context of the riot, contradictions may become apparent as they concern specific power relationships, in particular between: capitalist exploitation, racial domination, and sexual oppression.

The issue opens with a conversation between Verónica Gago and Raquel Gutiérrez Aguilar, titled “The Feminist Strike as Threshold.” In the introduction to this conversation, Brazilian scholar Tatiana Oliveira poses one of the key questions expressed in this extraordinary conversation: What happens with these struggles that are able to project themselves in a massive scale without losing their minoritarian vector? It is precisely here that the answer to this question positions the feminist strike as a threshold, which is to say, as an instance of actuality in the direction of a new political technology of social struggle that also generates a change in the "riot" as a political concept - the question we are grappling with throughout this issue. This leads us to adopt and adapt the categories and practices of struggle, given how social forces intervene in, and actualize, the ways of feeling, seeing, thinking, speaking and acting politically. In the context of the crisis of democracy and the reconfiguration of neoliberal modalities of extraction, the 
feminist strike allows us to "not renounce desire in its ethic to affirm life," thereby reconnecting individual and collective experiences with the struggles themselves.

Joshua Clover's article "Riot, Strike, Commune: Gendering a Civil War” points to what he calls a "methodological historical materialism," by emphasizing the need to understand the heterogeneity of any situation as well as a diachronic theory of change. Starting from this perspective and from his book Riot. Strike. Riot, he analyzes the entanglement of repertoires of collective struggle and the transformations of patterns of capital accumulation. To overcome this separation, Clover reflects on the commune as coming in the wake of the riot. He emphasizes the gendered aspect of the commune's sphere of reproduction that makes possible the double confrontation of a counter-reproduction.

The series of discussions continues with a text produced from the experience of the recent international feminist strike in Argentina. The author, Lucía Cavallero, in the article "Work, Debt and Reproduction: the Feminist Strike as a Revolution of Daily Life" proposes thinking about the strike of the feminist movement as a blockade and interruption of tasks both in the productive and reproductive fields that go beyond the classic concept of strike. At the same time she proposes thinking about how the feminist strike demonstrates the invasion of finance in ever more spaces of the reproduction of life.

The labor, the bodies, and the revolts of women are also woven together in the article by Ana María Morales Troya titled "We Were like Slaves, All Women. But We Won't Come Back." Morales Troya focuses on the historic rebellions sparked by the disappearance of the hacienda in an Afro-Ecuadorian community with an analysis of reproduction and coloniality, as well as the adoption of an intersectional perspective, all of which weave together a space of reflection about the relationship between bodies, territories, violence, and resistance that they inhabit.

Nicolás Cuello's article titled “Queering the Protest's Temporalities,” proposes a journey through the artistic activism of sexual dissidents' movements in Argentina from the post-dictatorship to the present day, postulating that there is an alternative temporality in their political practices.

Also focusing in the Southern Cone, in "Collective Violence and Politics in Argentina," Leandro Gamallo thinks through the relationship between collective violence and politics. He considers the transformation of the concept of violence and its supposed depoliticization, and grapples with the notion of "riot" by undertaking a sociological investigation about various violent episodes in Argentina.

In "Trans-border Friendships and Strategic Inclinations: Some Insights on the Molecular Emergence of Subversion in Chile” Patricio Azócar Donoso and Hugo Sir Retamales grapple with the Chilean neoliberal experiment and what they call its libidinal infrastructure of plunder and surrender. Traversing this dystopia-catastrophe, they trace a genealogy of the insurrections in Chile in 2006 and 2011. They 
also consider the broader Latin American context, and the alliances that have threatened the post-dictatorship consensus there too, as well as the ways that these alliances, especially those that crisscross borders of all types, are being hunted down.

Continuing to think through riots from the Global South, Niharika Singh's article "Protest and the City," presents a theoretical analysis based on contemporary experiences in universities of New Delhi with a narrative of conflict. She presents a complex grid of interpretation that starts from the concept of "attachment" and its flow in and out of a network wherever bodies gather (assemblies, demonstrations, strikes, riots) and then reflects on a series of experiences analyzed through this matrix. The article concludes with a discussion about the ideas of vulnerability, capacity and creation, and their political significance.

Moving northward, Duncan Tarr's "Crossed Wires in the Motor City: A Genealogy and Analysis of the 1967 Riots and the 1968 Strike Wave in Detroit” analyzes the transitional riotous period of the late 1960s in Detroit, and the struggle of Black proletarians in the Motor City. Between 1967 and 1968 these partisans of riot became partisans of strike - supplementing Joshua Clover's investigations on the riot and the strike. Unsurprisingly, the strike actions, and the ways they were theorized by the rebels themselves, retain echoes of the 1967 riot. Tarr focuses on the entanglement of the riot and strike and its materialization in the way in which Black workers were treated as surplus even while employed in the plants, as well as on the strategies by which the rebels sought to disrupt the circulation of commodities.

Lastly, Alejo Stark's essay “Containing the Surplus Rebellion: Prison Strike/ Prison Riot" provides a characterization of the recent prison strike/riots in the United States and its relation to what some have called "the age of riots.” By linking the struggles raging inside prisons in the United States today (a country which has the highest incarceration rate in the world) with the struggles in the streets (e. g., the riots that broke out in Ferguson and Baltimore in 2014 and 2015) Stark points to the state's continuous attempt to contain the riot and the struggles of racialized surplus populations both inside and outside prison walls.

To conclude, this forum represents one step toward grappling with an underinvestigated social and political phenomenon in our global era: the riot. By approaching the riot through a plurality of approaches and perspectives, we may emphasize the necessity of a complex understanding of the "riot," and to demonstrate the urgency - for both scholars and militants - to heed its specific forms of struggle. 